\title{
MICONIA ELAEAGNOIDES: A MORPHOLOGICALLY DISTINCTIVE SPECIES WITHIN THE CARIBBEAN CLADE OF MICONIA (MELASTOMATACEAE: MICONIEAE)
}

\author{
Walter S. Judd and Lucas C. Majure \\ Dept. of Biology and Florida Museum of Natural History \\ University of Florida \\ Gainesville, Florida 32611-7800, U.S.A. \\ Iyonia@ufl.edu; Imajure@fImnh.ufl.edu
}

\begin{abstract}
Miconia elaeagnoides, a morphologically distinctive species traditionally circumscribed within Tetrazygia, is provided with an updated description and nomenclatural assessment, along with a consideration of phenology, distribution and habitat, and citation of specimens examined. The species exhibits an unusual combination of characters, e.g., flowers with relatively long pedicels (and so well separated) even though their pseudopedicels are nearly sessile, an irregularly opening calyx-calyptra, four obovate petals, a 4-loculate, strongly lobed ovary, and fruit with a constricted calyx. Miconia elaeagnoides is resolved within the Caribbean clade of Miconia, and within this species-rich group it is possibly related to the species of the M. longicollis clade.
\end{abstract}

\section{RESUMEN}

Se presenta Miconia elaeagnoides, una especie morfológicamente distinta y tradicionalmente circunscrita en Tetrazygia, con una descripción actualizada y revisión nomenclatural, con una consideración de su fenología, distribución, hábitat y citación de especímenes examinados. La especie exhibe una combinación inusual de caracteres_flores con un pedicelo relativamente largo (entonces están bien separadas) aunque sus pseudopedicelos son casi sésiles, un cáliz con caliptra, que se abre irregularmente, cuatro pétalos obovados, un ovario 4-locular, fuertemente lobado y el fruto con un cáliz estrecho. Se resuelve Miconia elaeagnoides como parte del clado caribeño de Miconia, y dentro de este grupo con una alta riqueza de especies, está posiblemente relacionado con las especies del clado de M. longicollis.

In the course of recent investigations into the systematics and phylogeny of the tribe Miconieae (Melastomataceae), a number of taxonomic problems have come to light. We have focused on issues related to the Caribbean species of the widespread and megadiverse genus, Miconia sensu lato. Recent phylogenetic analyses (Bécquer et al. 2008; Goldenberg et al. 2008; Majure et al. 2014, 2015, 2018; Martin et al. 2008; Michelangeli et al. 2008; Michelangeli et al., submitted) have shown the necessity for major changes in generic circumscription within the tribe, due to massive polyphyly. We here adopt a broad circumscription of Miconia, comprising the DNA-supported clade within Miconieae that can be diagnosed by the synapomorphy of berry fruits (see also Gambia \& Almeda 2014; Ionta et al. 2012; Judd et al. 2014a, b, 2015c; Majure et al. 2014, 2015, 2018; Michelangeli et al. 2018). Miconia long has been conserved against Leonicenia Scop. (Briquet 1906), and recently was conserved against Tococa Aubl. and Maieta Aubl. at the International Botanical Congress in Shenzhen (Michelangeli et al. 2016; Turland et al. 2017). The necessary new names and combinations have been proposed/made in a series of taxonomic revisions (e.g., see those listed in the following paragraph) and in Michelangeli et al. (2018).

Within Miconia s.l., major clades supported by recent and ongoing phylogenetic investigations have been recognized at the sectional level when morphologically diagnosable; e.g., sect. Calycodomatia Skean, Judd, Majure, \& Bécquer (Majure et al. 2015, 2018), sect. Calycopteris Judd, Bécquer, \& Majure (Judd et al. 2014a; Bécquer et al. 2017/18), sect. Chaenopleura (Rich. ex DC.) Hook. (Bécquer \& Michelangeli 2011; Judd 2007; Judd et al. 2015a, b, 2017), sect. Echinatae Judd, Bécquer, \& Majure (Majure et al. 2015; Judd et al. in prep.), sect. Krugiophytum (Cogn.) Majure \& Judd (Majure et al. 2014/15), sect. Lima Majure \& Judd (Majure \& Judd 2013; Majure et al. 2016), sect. Miconiastrum (Bonpl. ex Naudin) Judd, Bécquer, \& Majure (Judd et al. 2014b), sect. Sagraea (DC.) Ionta, Judd, \& Skean (Ionta et al. 2012; Judd \& Ionta 2017; Judd et al. 2018), and sect. Sagraeoides 
(Skean) Skean, Judd, Majure, \& Ionta (Judd et al. 2015c; Skean 1993, 2000; Skean et al. 2018), although some clades have received only informal recognition, e.g., the Octopleura clade (Gambia \& Almeda 2014), the Miconia crotonifolia complex (Judd \& Ionta 2013), and the Miconia ulmarioides complex (Tiernan \& Michelangeli 2018). One such clade, only recognized informally, is the Caribbean clade of Miconia (Judd 2019; Majure et al. 2014/15, 2015, 2018), which represents one of the major radiations of Miconia within the Greater and Lesser Antilles (Michelangeli et al. 2008), comprising some 155 morphologically diverse species. These can be placed into 15 morphologically diagnosable subclades, some currently named (see below), but many still unnamed. A detailed, higher-level classification of the Caribbean clade, based on morphological and molecular data, is in preparation (Majure et al., in prep.). An enumeration of these subclades is beyond the scope of this paper. The Caribbean clade is nearly exclusively restricted to the Caribbean region, although Miconia lundelliana L.O. Williams (of the Pachyanthus clade) grows in Belize, Honduras, and Nicaragua, and M. bicolor (Mill.) Triana (of sect. Miconiastrum) reaches southern Florida.

In the course of work on the species of Miconia occurring in the Greater Antilles, we encountered (and the first author collected) Miconia elaeagnoides, the subject of this paper: a distinctive species of previously uncertain phylogenetic position whose 4-merous flowers each have an extremely short pseudopedicel and fairly elongated pedicel, a membranaceous, irregularly rupturing calyx-calyptra, a more or less constricted hypanthium, and a fully inferior, 4-lobed and loculate ovary. This species is almost surely a member of the Caribbean clade of Miconia, as designated in Goldenberg et al. (2008) and Michelangeli et al. (2008). Phylogenetic analyses based on DNA-sequence variation place the species within this clade (Michelangeli et al., submitted), in agreement with morphological evidence, as outlined below. Its inflorescences are terminal, ruling out a placement in either Miconia sects. Sagraeoides or Sagraea, as these two sections, both very diverse in the Greater Antilles, have axillary inflorescences. Additionally, a placement in either of these two clades is ruled out by indumentum characters. Miconia elaeagnoides has globular-stellate hairs, while the multicellular hairs of species of sect. Sagraeoides are elongate, unbranched to branched, and thin-walled (see Skean 1993, fig. 3; see also Judd et al. 2015c and Skean et al. 2018). Species of sect. Sagraea have distinctive hairs that are short-stalked with an expanded, glandular head in which the individual cells are separated by furrows (see Ionta et al. 2012, fig. 1A; Wurdack 1986, figs. 51, 52, 54-56). These hair types are probably synapomorphic for each of these two clades, and it is thus significant that such hairs are absent in M. elaeagnoides. Placement of M. elaeagnoides in another major Antillean radiation, represented by sect. Chaenopleura (Rich. ex DC.) Benth. \& Hook.f., is countered by floral morphology. The flowers of M. elaeagnoides are zygomorphic (due to placement of the androecium), the calyx is calyptrate, the anthers are bright yellow, subulate, open by a small dorso-apical pore, and lack any dorsal projections on the connective. In contrast, the species of sect. Chaenopleura have radially symmetrical flowers in which the stamens form a ring, the calyx has distinct lobes, the anthers are white, obovate, open by four longitudinal slits, and have a connective with a mid-dorsal bump. These androecial characters are likely synapomorphic for the species of sect. Chaenopleura. Thus, a placement of M. elaeagnoides within the Caribbean clade is suggested through a process of elimination, as it is the only remaining major radiation of Miconia within the Greater Antilles (Judd 2019), although it is without definitive morphological synapomorphies.

There is weak support for the placement of Pachyanthus A. Rich. (Bécquer 2012) and Miconia sect. Miconiastrum (Judd et al. 2014b) as early divergent lineages within the Caribbean clade (Michelangeli et al., submitted) of Miconia. The remaining species of the Caribbean clade may form a poorly supported subclade showing the following putative synapomorphies: calyx teeth more or less twice the length of lobes or longer, flowers with four petals, and ovary with 4-locules (Majure et al. 2013). Miconia elaeagnoides lacks the diagnostic features of Pachyanthus (i.e., calyx tube tearing, petals clawed and heterogeneous in texture) and of sect. Miconiastrum (i.e., flowers 5-merous, stamens dropping before the petals abscise). Additionally, the species has flowers with four, white, obovate petals and 4-loculate ovaries, and in at least some individuals the calyx teeth are elongated (but assessment of calyx tooth length in relation to length of calyx lobes is difficult because the lobes are fused into a membranaceous cap), suggesting a placement among the more derived species of the Caribbean clade. Finally, M. elaeagnoides has fruits with a strongly constricted hypanthium (and thus was 
traditionally considered within the genus Tetrazygia Rich. ex DC.). Although this feature is highly homoplasious, nearly all of the species displaying such fruits are found within the Caribbean clade. By this rather elaborate series of arguments, therefore, morphology is seen to be in agreement with our molecular data, suggesting a placement of M. elaeagnoides within the Caribbean clade.

Recent revisionary work, as alluded to above, has resulted in the formal recognition of several subclades within the Caribbean clade at sectional rank, e.g., sect. Calycodomatia Skean, Judd, Majure, \& Bécquer (Majure et al. 2015, 2018; Skean 2010; Skean, in prep.), sect. Calycopteris Judd, Bécquer, \& Majure (Judd et al. 2014a; Bécquer et al. 2017/18), sect. Echinatae Judd, Bécquer, \& Majure (Majure et al. 2015; Judd et al., in prep.), sect. Krugiophytum (Cogn.) Majure \& Judd (Majure et al. 2014/15), sect. Lima Majure \& Judd (Majure \& Judd 2013; Majure et al. 2016), and sect. Miconiastrum (Bonpl. ex Naudin) Judd, Bécquer, \& Majure (Judd et al. 2014b). But some subclades of the Caribbean clade are still recognized at generic rank (e.g., Charianthus D. Don: Penneys \& Judd 2005; Pachyanthus: Bécquer 2012), although names within Miconia have already been provided for the species within these subclades. These clades will eventually be recognized infragenerically within Miconia. Many other subclades are currently under study but will eventually receive formal treatment (Majure et al., in prep.). One of these is the M. longicollis clade, a group of seven species, i.e., M. blancheana Urb., M. brachycentra (Griseb.) M. Gómez, M. cordilamina Judd \& Bécquer (= Tetrazygia cordata Alain), M. paralongicollis (Judd, Ionta, Clase, \& Skean) Judd \& Bécquer, M. pseudopedicellata Judd \& Bécquer (= Pachyanthus pedicellatus Urb.), M. rangeliana C. Wright ex Griseb. (= Tetrazygia laxiflora Naudin), and M. longicollis (Urb. \& Cogn.) Judd \& Bécquer, traditionally treated within Tetrazygia or Pachyanthus (although many other species of these two "genera" belong elsewhere; Michelangeli et al. 2008). The precise placement of Miconia elaeagnoides within the Caribbean clade is somewhat problematic based on DNA-sequence data. Our analyses (Majure et al., in prep.) suggest, with poor statistical support, that M. elaeagnoides may be related to the species of the M. longicollis clade. Several species of this clade resemble M. elaeagnoides in having flowers with very short pseudopedicels, an unusual characteristic among species of the Caribbean clade. Most also show fruits with a strongly constricted calyx and elongated calyx teeth. Additionally, M. longicollis and M. paralongicollis have strongly 4-lobed ovaries. All these features are also characteristic of M. elaeagnoides. More phylogenetic work is required, but we herein place the morphologically distinctive M. elaeagnoides in the Caribbean clade, as a possible relative of the M. longicollis group. Among these species M. elaeagnoides is most similar to M. longicollis and M. paralongicollis, but it differs in the presence of a calyptrate calyx (lacking in M. longicollis and relatives). Additionally, it has smaller flowers, i.e., hypanthium $2.7-4 \mathrm{~mm}$ long, with the free portion 1.7-2.5 mm long, and the ovary 1.3-2.2 mm long. Although M. elaeagnoides has occasionally been misidentified as M. longicollis, it has more frequently been confused with M. angustifolia (Sw.) Griseb., a species that is similar vegetatively but differs markedly in several reproductive characters and is likely not closely related. Miconia angustifolia differs in its flowers with distinct calyx lobes (vs. a calyptrate calyx in M. elaeagnoides), pink to purple petals to ca. 2 $\mathrm{mm}$ long (vs. white petals, 5.6-12 mm long), and a globose (vs. 4-lobed) ovary. The flowers are arranged in many-flowered corymbiform inflorescences (vs. few-flowered inflorescences), each flower with an evident (vs. more or less sessile) pseudopedicel (see also Liogier 2000).

We provide a nomenclatural assessment and updated description of this enigmatic and morphologically distinctive species, along with an assessment of phenology, distribution and habitat, and citation of specimens examined. Measurements included in the description were taken directly from dried material, with these exceptions: 1) plant height and flower/fruit color, are based on information from specimen labels, observations in the field, or from photographs, and 2) floral measurements, were made from rehydrated material. Measurements of floral parts follows Judd (2007) and Judd et al. (2014a, b), along with guidelines for contributors to the on-line monograph of Miconieae (Michelangeli et al. 2009 onward).

Miconia elaeagnoides (Sw.) Griseb., Goett. Abh. 7:69. 1857. Melastoma elaeagnoides Sw., Prodr. 72.1788 [as aeleagnoides]. Tetrazygia elaeagnoides (Sw.) DC., Prodr. 3:172. 1828. Type: India Occidentali, hb. Casströmii [St. John, U.S. Virgin Islands], fl, J. Ryan [?] s.n. (LECTOTYPE, designated by Howard \& Kellogg, 1986: BM; ISOLECTOTYPE: S, digital image \#S-R-3458!). 
Tetrazygia fuertesii Cogn., in Urban, Symb. Antill. 7:526. 1913. Type: Dominican Republic. Prov. Barahona. Paradis, 25 m, Jul 1910, fl, M. D. Fuertes 477 (LECTOtype, here selected: NY \#00099756!; Isolectotypes: E, NY \#01101187!, US!). [Note: The remaining syntype, Fuertes 926, not seen.]

Shrub or tree to $10 \mathrm{~m}$ tall, with \pm gray, vertically furrowed bark. Indumentum of only multicellular, white to pale ferrugineous, globular-stellate hairs. Young twigs 1-2.5 mm wide, ellipsoidal to flattened-ellipsoidal in cross section, sometimes with a median longitudinal groove, and becoming terete with age, with moderate to dense globular-stellate hairs; internodes $0.3-8.7 \mathrm{~cm}$ long, nodal line absent. Leaves opposite and decussate, isophyllous or nearly so to slightly anisophyllous, with petiole $2.5-22 \mathrm{~mm}$ long, with dense globular-stellate hairs; blade (1.7-)2-15 × 0.4-3.2 cm, 2.3-6.3 times longer than wide, ovate to elliptic or narrowly so, occasionally oblong, chartaceous to thinly coriaceous, apex acute or occasionally obtuse or slightly acuminate, base acute to rounded, margin entire and not ciliate; venation acrodromous, usually basal, but appearing suprabasal as major secondary vein pair arising above leaf base, with prominent midvein and 2 or 4 secondary veins, 1 pair conspicuous and 1 pair inconspicuous or absent, the 2 conspicuous secondary veins positioned $0.5-5 \mathrm{~mm}$ in from margin, and 2 inconspicuous secondary veins \pm intramarginal to $1 \mathrm{~mm}$ from margin, tertiary veins percurrent, oriented subperpendicular to midvein, $0.8-6 \mathrm{~mm}$ apart, connected by quaternary veins, the higher order veins reticulate, often obscure, midvein and major secondary veins moderate to slightly impressed, tertiary veins very slightly impressed to flat, remaining veins flat on adaxial surface, midvein conspicuously raised, major secondary veins strongly to moderately raised, minor secondary veins slightly raised to flat, tertiary veins slightly raised to flat, and higher-order veins flat on abaxial surface; adaxial surface green, with visible druse crystals, indumentum initially of \pm moderate globular-stellate hairs, becoming glabrous with age; abaxial surface with dense, white to \pm pale ferrugineous, globular-stellate hairs, these $0.1-0.15 \mathrm{~mm}$ across. Hair tuft domatia absent. Inflorescences terminal, with shoots producing several nodes before becoming reproductive, \pm reduced to paniculate or elongate cyme of (1-)3-30 flowers, (1-)1.5-5.5 cm long, 1.2-6.5 cm across, with 0-3 major branch pairs; proximal segment of lowermost inflorescence branches $0.2-3.4 \mathrm{~cm}$ long, with dense, globular-stellate hairs, ultimate axes (pseudopedicels) $\pm 0 \mathrm{~mm}$ long, but flowers \pm well separated (due to elongate pedicels); peduncle $0.2-3.7 \mathrm{~cm}$ long, with similar indumentum; bracts $0.3-10 \times 0.2-1 \mathrm{~mm}$ (the lowermost occasionally larger, intergrading with leaves), not involucrate, triangular to linear (or occasionally narrowly elliptic), acute apex, deciduous or occasionally persistent (but lowermost quickly deciduous), with globular-stellate hairs; bracteoles $0.2-1 \times 0.15-0.5 \mathrm{~mm}$, with acute to rounded apex, deciduous or persistent, with globular-stellate hairs. Flowers 4-merous (very rarely a few 5-merous), zygomorphic (due to androecium placed on one side of the flower), with pedicel 1-4 mm long. Hypanthium 2.7-4 mm long, conic and basally (i.e., where adnate to ovary) 4-lobed, slightly to moderately constricted above ovary; free portion 1.7-2.5 mm long, 1.5-3 mm wide at the torus, outer surface with moderately scattered to dense, ferrugineous to white, globular-stellate hairs, inner surface smooth to slightly longitudinally ridged, glabrous or with a few branched hairs, androecial fringe absent. Calyx lobes 4, fused into a hemispheric, apiculate, membranaceous calyptra, irregularly rupturing early in anthesis, the "lobes" with proximal portion herbaceous and distal portion membranaceous, irregular, appearing broadly triangular to \pm obsolete, rounded to acute at apex, abaxially with hairs similar to those of the hypanthium, and adaxially nearly glabrous or with minute globular hairs; calyx teeth present, $0.3-1.4 \mathrm{~mm}$ long, a short bump to terete projection, \pm erect to spreading, with acute apex, scattered globular-stellate hairs. Petals 4, 5.6-12 $\times 4.1-8 \mathrm{~mm}$, asymmetrically obovate, with or without a basal lobe on one side, spreading, white, glabrous but with bullate to papillate cells, apex rounded, base narrowed and sometimes with claw-like base, margin entire. Stamens 8, isomorphic, with filaments apically geniculate; staminal filament 3.9-8 mm long, glabrous, white, sometimes pink-tinged, anther 4-6.3 × 0.7-1.1 mm, subulate, straight to incurved or slightly recurved, opening by a small dorso-apical pore, bright yellow, the connective not prolonged below thecae and not appendaged, glabrous. Ovary 4-locular, 1.3-2.2 mm long, 1.3-3.7 mm across, completely inferior, 4-lobed, apically flat to slightly concave, with a few branched hairs, especially apically, apex with collar and crown-like fringe of branched-hairs, with axile placentation, ovules numerous, borne on expanded placenta that extends into each locule; style 8-17.5 mm long, terete, not swollen, apically 
curved, white, glabrous; stigma truncate to punctate, minutely papillose, ca. 0.2-0.3 mm wide. Berries 3-9 $\mathrm{mm}$ long (excluding hypanthium/calyx, and including slightly immature as well as fully mature fruits), 6.5-10 $\mathrm{mm}$ in diameter (including both slightly immature and fully mature fruits), subglobose to globose and \pm 4-lobed, gradually expanding when green, then rapidly increasing in size and turning purple- or blue-black at maturity, with minute, branched to globular-stellate hairs, hypanthium clearly constricted above ovary. Seeds 0.7-1.1 mm long, angular-obovoid, with flat, \pm rectangular to linear, dark hilum, the testa \pm smooth; appendage absent.

Phenology.-Collected in flower in every month of the year except August and September, so probably more or less continuingly blooming (and fruiting).

Distribution and habitat.-Miconia elaeagnoides grows on Hispaniola (Dominican Republic and Haiti, incl. Ile de la Tortue) in the lower elevations of the Massif du Nord, Cordillera Central, Sierra Martín Garciá, and also in lower elevation, coastal, karstic regions (Fig. 1); on Puerto Rico (incl. Isla de Vieques) in karstic regions, limestone hills, especially in coastal regions (Fig. 1); and in the U.S. Virgin Islands (St. Croix, St. John, St. Thomas) and British Virgin Islands (Virgin Gorda; possibly also Tortola, see Britton \& Wilson 1925), on limestone. The species is characteristic of moist to dry forests on limestone, thickets, and rocky, limestone areas from sea-level to $825 \mathrm{~m}$. It has been well collected, especially in Puerto Rico. The species was early reported from Martinique, in the Lesser Antilles, but no collections have been seen (see also Cogniaux 1891; Fournet 1978; Urban 1921). The plant Tetrazygia elaeagnoides (Sw.) DC. var. martinicensis Naudin (Ann. Sci. Nat. ser. 3, 15:343, 1851; type not seen), collected in Martinique, is probably based on a different plant, not only because Martinique, in the Lesser Antilles, is geographically distant from the species confirmed range, but also because Naudin stated that the Martinique plant had softer, more obtuse (vs. chartaceous to thinly coriaceous, usually acute) leaves, and smaller flowers with more conspicuous external calyx teeth (vs. such teeth only 0.3-1.4 mm long).

Vegetative anatomy.-The vegetative anatomy of Miconia elaeagnoides was investigated by Judd et al. (2008; as assessed in Judd 6553) and is typical for species of Miconia. The petioles have a U-shaped pattern of seven vascular bundles, with the individual bundles composed of xylem surrounded by phloem. The ground parenchyma is unlignified and there are only a few lignified idioblasts or such cells are absent; druse crystals are abundant. The leaves have dorsoventral blades with an epidermis, palisade and spongy mesophyll; the midvein has several vascular bundles, which are more or less arranged in a ring. Lignified idioblasts and fibers are absent, but again the parenchyma tissue surrounding the vascular bundles of the lamina midvein is packed with druses.

Additional specimens examined. DOMINICAN REPUBLIC. Prov. Azua: Sierra Martin García, Municipio Azua, Sección Barrera, Alto El Yarey, camino hacia Los Negros de la Costa, 18¹8'44"N, 7053'52"W, 300-400 m, 30 Jul 2003, Clase et al. 3612 (FLAS, JBSD, MO); Sierra Martín García, al S del poblado de Barrero, cerca de la divisoria entre las prov. de Azua y Barahona, en el lugar llamado "El Copey," 18¹8.5'N, 7055'W, 700-750 m, 4 Sep 1986, García \& Pimentel 1750 (FLAS, JBSD); Sierra Martín García, Loma del Aguacate, W of Barreras, 825 m, 17 May 1992, Judd et al. 6553 (FLAS, JBSD); SW of Barreras, along trail from Barreras toward El Copey, 18¹9'5.8" N, 7056'40.6"W, 760 m, 6Jun 2006, Judd et al. 8151 (FLAS, JBSD, MO, NY, S, US); Sierra Martín García, Alto la Yagua, 7-8 km al suroeste de Barrero, $18^{\circ} 19^{\prime} \mathrm{N}, 70^{\circ} 55^{\prime} \mathrm{W}$, 400-500 m, 13 Nov 1983, Pimentel et al. 345 (JBSD); Sierra Martín García, 18¹8' N, 7056’W, 500 m, 23 Feb 1987, Zanoni et al. 38423 (FLAS, JBSD, MO, NY, US). Prov. Barahona: without definite locality, 1912, Fuertes 1584 (F, GH, NY, US); along Rt. 44 ca. 8.3 km N of Enriquillo, $17^{\circ} 56^{\prime} 11.6^{\prime \prime} \mathrm{N}, 71^{\circ} 12^{\prime} 18.1 \mathrm{~W}, 70 \mathrm{~m}, 5$ Jun 2006, Judd et al. 8146 (FLAS, JBSD, US); along Rt. 44, $10 \mathrm{~km}$ S of Los Patos, $8.3 \mathrm{~km}$ N of Enriquillo,

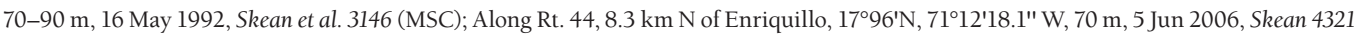
(FLAS); "Los Morones," area 2-4 km up Río Baoruco from the river mouth (town of Baoruco), via trail to Las Auyamas, $18^{\circ} 05^{\prime} \mathrm{N}, 71^{\circ} 07^{\prime} \mathrm{W}$, 40-100 m, 19 May 1981, Zanoni et al. 13473 (JBSD, MO, NY). Prov. Hato Mayor: Los Haitises, entre Cueva La Arena y la Boca de la Bahía de San Lorenzo (Oeste de Sabana de la Mar), en farallones de caliza, orilla de la Bahía de Samaná, el Parque Nacional de Los Haitises, $19^{\circ} 05^{\prime} \mathrm{N}$, 69²7'W, 0-10 m, 29 Jun 1982, Zanoni et al. 21103 (FLAS, JBSD, MO, NY). Prov. Independencia: Sierra de Bahoruco, aprox. $7.5 \mathrm{~km}$ al S de Duvergé, camino a Monte Palma, 18²1'N, 7129.5'W, 700 m, 23 Mar 1993, García et al. 4409 (FLAS, JBSD); Sierra de Bahoruco, sur de Duvergé, entrando al E del pueblo, en el firme de La Cañita, sur de Monte Palma, aprox. 2 horas y media desde Duvergé en mulo, $18^{\circ} 17^{\prime} \mathrm{N}$, 71³0.5'W, 700-750 m, 3 Dec 1993, García et al. 5290 (JBSD). Prov. Samaná: Peninsula de Samaná, Cabo Samaná, near the lighthouse, 8 May 1930, Ekman H14911 (S); Samaná, Boca de Río San Juan, 17 May 1930, Ekman H15008 (NY, S); on seashore, near the mouth of Barracote River, Samaná Bay, Los Haitises, 19 Mar 1969, Liogier 14526 (NY, US); Península de Samaná, El Faro, Cabo Samaná, 80 m, 21 Jul 1993 , Salazar et al. 590 (MO); en la parte nordeste de la Península, Loma El Frontón, 19¹7'N, 69¹0'W, 100-256 m, 20 Mar 1984, Zanoni et al. 


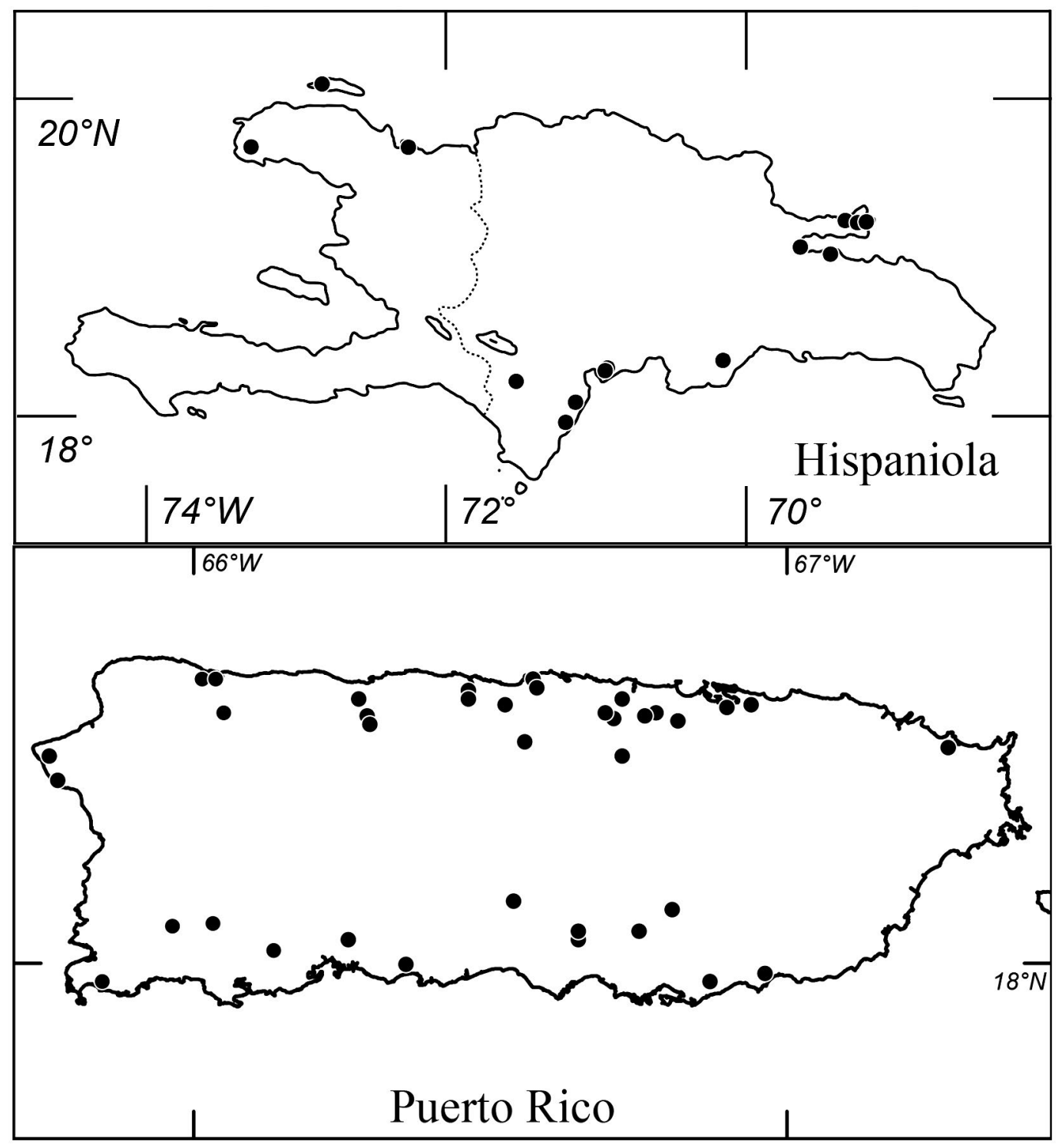

FIG. 1. Distribution of Miconia elaeagnoides on Hispaniola and Puerto Rico.

29322 (FLAS, JBSD). Prov. San Cristobal: Cordillera Central, 12 km al oeste de la ciudad de San Cristóbal, en la carretera que va de Cambita Garabito hacia Valentín, entre Mucha Agua y La Colé, 18²8'N, 70¹7'W, 440 m, 26 Jun 1984, Mejía et al. 864 (FLAS, JBSD, NY). HAITI. Dept du Nord: Massif du Nord, Cap-Haitien, Morne La Vigie, 300 m, 1 Dec 1924, Ekman H2713 (S, US). Dept. du Nord Ouest: Presqu-ile du Nord-Ouest, Port-de-Paix, at Cordier, 27 Apr 1925, Ekman H3926 (S); Ile La Tortue, La Vallée, 20 May 1925, Ekman H4047 (A, GH, NY, S, US); in the La Vallée valley, vicinity of La Vallée, 31 Dec 1928, Leonard \& Leonard 11338 (NY, US); ibid., Leonard E Leonard 11341 (US); ibid., Leonard \& Leonard 11342 (A, MICH, MO, US); Bombardopolis rd S of Mole gorge, 13-19 Feb 1929, Leonard E Leonard 13235 (GH); vicinity of La Vallée, Tortue Island, old railroad bed on W bank of La Vallée valley, 5 May 1929, Leonard E Leonard 15368 (US); along Au Palmiste trail, vicinity of La Vallée, Tortue Island, 3-10 May 1929, Leonard \& Leonard 15581 (NY, US). PUERTO RICO. Quebradillas, Bo. Terranova, sector La Estación, 18²8.983'N, 6655.117'W, 100 m, 22 Dec 1994, Acevedo-Rdgz. 7018 (MO, NY); Mun. Quebradillas, 18²9'N, 6656'W, 4 Nov 1994, Atha et al. 712 (NY); Mun. Isabella, Rt 2 at Guajataca Gorge, ca. 300 m W of Rio Guajataca and 300 m E of intersection with Rt 113, 
$18^{\circ} 29^{\prime} \mathrm{N}, 66^{\circ} 57^{\prime} \mathrm{W}, 30 \mathrm{~m}$, $23 \mathrm{Jan}$ 1998, Atha E Cedeño 1854 (NY); Las Piedras Chiquitas, trail from house at Rt $717 \mathrm{~km} 2.1$, whole ridge and N side of peak, 450-550 m, 24 Nov 1990, Axelrod 1794 (NY); Coamo, Las Piedras Chiquitas, trail on spur from Rt 717, km 2.1, in ravine E of where spur meets main ridge, 475-500 m, 3 Mar 1991, Axelrod \& Wells 2119 (MO); Vieques, Monte Pirata, N slope along rd, 225-250 m, 25 Jul 1992, Axelrod et al. 4919 (NY); Bayamon, Bo. Hato Tejas, W of Rt 871, W mogote near convent, 50-100 m, 9 Dec 1992, Axelrod et al. 5522 (MO); Coamo, Bo. Pasto, Rt 155, km 6.8, 18066.84'N, 66²2.84'W, 375 m, 30 Nov 2002, Axelrod et al. 12347 (MO, US); ibid., Axelrod 12354 (MO, US); Vega Baja, 26 Mar 1906, Britton \& Cowell 1437 (F, NY, US); NW of Ponce, 8 Mar 1913, Britton \& Shafer 1740 (NY, US); Camuy to Quebradillas, 2 Mar 1914, Britton \& Cowell 1947 (NY); vicinity of Coamo Springs, 25 Feb 1922, Britton et al. 6243 (F, NY); vicinity of Dorado, 20-22 Mar 1922, Britton et al. 6643 (F, NY); E of Vega Alta, 29 Jan 1923, Britton \& Britton 7125 (NY, US); Corozal, 7 Mar 1923, Britton \& Britton 7835 (NY); Bau[ta] R[iver], illegible, 12 Feb 1927, Britton \& Britton 8826 (NY, S); without definite location, Duke s.n. (MO); NE slopes of Cerro Pirata, 200 m, 5 Jun 1978, Fosberg 57634 (US); Quebradillas, near Balneario Guanajataca, 18²9'N, 6658'W, 50-200 m, 4 Apr 1985, Gentry \& Zardini 50422 (MO, US); Villalba, 15 Mar 1935, Gerhart 241 (NY); near San Juan, 20 Jul 1935, Gerhart \& Holdridge 526 (NY); Toa Alta, 2 Dec 1899, Goll 914 (NY, US); Bereda, Vega Baja, 8 Dec 1899, Goll 1030 (NY, US); Vieques, Jul 1978, Griffis \& Brokx s.n. (NY); Mun. de Manatí, ca. 0.5 mi S of Manatí, along Hwy 149, 0.4 mi S of jct with Hwy 2, 17 Nov 1981, Hansen et al. 9071 (MO, NY); Mun. de Vega Alta, along Rt 691, 1.7 mi NW of jct with Rt 695, ca. 2 mi N of Vega Alta, 24 Nov 1981, Hansen et al. 9311 (FLAS); 2 mi W of Bayamon, 29 Apr 1899, Heller E Heller 1235 (F, NY, US); Lago San Jose, 14 Sep 1912, Horam s.n. (NY); ravine on coastal Rt 901 between Yabuco and Maunabo, 10 Feb 1969 , Howard 17256 (A, DUKE, MO); Bayamon, 3 Aug 1913, Johnston 907 (NY, US); Toa Alta, 200 m, 14 Apr 1979, Liogier \& Liogier 28669 (MO, NY); Sabana Grande, 100 m, 3 Oct 1979, Liogier et al. 29578 (NY); La Joya, Rincón, 100 m, 11 Feb 1981, Liogier et al. 31660 (NY, US); Corozal, 300 m, 1 Dec 1983, Liogier \& Martorell 34840 (MO); near Corozal, 400 m, 1 Dec 1983, Liogier \& Martorell 34851 (NY); Rt 486, km 6.7, S of Camuy, 300 m, 26 Feb 1986, Liogier \& Martorell 35951 (MO, NY, US); without definite locality, 14 Jun 1950, Little 13010 (F, NY, US); Bosque Experimental Cambalache, 100 ft, 24 Jul 1950, Little 13433 (A, F, NY, US); Arecibo, 100 yards E of Rt 10 on intersection with Rt 661, $18^{\circ} 19^{\prime} 57^{\prime \prime} \mathrm{N}, 66^{\circ} 40^{\prime} 37^{\prime \prime} \mathrm{W}, 315 \mathrm{~m}, 12$ Nov 2012, Michelangeli \& Aguirre-Santoro 1997 (NY); Mun. Toa Alta, along Rt 677, 2 mi S of Rt 2, $18^{\circ} 16^{\prime} \mathrm{N}$, $66^{\circ} 17^{\prime} \mathrm{W}, 110 \mathrm{~m}$, Miller \& Taylor 5914 (MO); Mun. Añasco, Bo. Caguabo, around stone quarry above Hwy 115, just W of jct with Hwy 402, $18^{\circ} 18^{\prime} \mathrm{N}, 67^{\circ} 12^{\prime} 30^{\prime \prime} \mathrm{W}, 10$ m, 9 Nov 1993, Nee 44165 (MO, NY); Mun. Cabo Rojo, Sierra Bermeja, Barrio Llanos Costa, upper slopes and summit of Cerro Mariquita, 250-301 m, 11 Oct 1987, Proctor \& McKenzie 44027 (US); Mate de Platano Research Station, 21 Dec 2004, Richardson 117 (FLAS); Rt 10, S of Arecibo, N of Rt 626, 45 m, 21 Jun 1993, Salzman \& Zona 244 (FLAS); Rincon, 22 May 1937, Sargent A21 (MO, US); San German, 6 Apr 1935, Sargent 479 (MO, US); Vieques Island, Cerro Ventana, 150-340 m, 20-21 Feb 1914, Shafer 2993 (NY, US); Guayama, ca. Guamani, 12 Oct 1885, Sintenis 2243 (GH, S); inter Aibonito et Algarrobo, 2 Dec 1885, Sintenis 2945 (US); Peñuelas, 10 Jun 1886, Sintenis 4532 (GH, NY, S, US); Rincon, 1 Dec 1886, Sintenis 5305 (US); ibid., Sintenis 5505 (F, MO, NY, S); prope Quebradillas, Jun 1887, Stahl 732 (S); Quebradillas, 18 May 1913, Stevens 2062 (NY); Garrochales, 6 Dec 1914, Stevenson 2401 (NY); Espinosa, 5 Oct 1915, Stevenson 3120 (US); Mun. de San German, southern foothills of the Cordillera Central, near Rt. 119, 25 Jun 1966, Stimson 2996 (DUKE, FLAS, GH, MICH, MO, NY, US); Mun. de Yauco, N of Susua, 27 Jun 1966, Stimson 3044 (DUKE, FLAS, GH, MICH, MO, NY, US); Mun. de Guayama, along trail S from Rt 712 ca. 1-1.5 km W of its intersection with Rt 15, 19 Nov 1985, Taylor 6466 (DUKE); Mun. de Coamo, NW of Coamo, at intersection of Rt 155 and Rt 555, 7 May 1988, Taylor 8053 (NY); Mun. de Cayey, Rt 708 from Jajome Bajo to ca. 2 km N of Rt 712 at La Plena, 14 May 1988 , Taylor \& Ross 8073 (NY); Mun. Quebradillas, Rt 437 ca. 1-2 km S of Rt 113, 18²5'N, 66 $55^{\prime} \mathrm{W}, 100-200$ m, 24 Jun 1991, Taylor $\&$ Gereau 10499 (MO, NY); Isabela, Bosque Estatal de Guajataca, Montanas Aymamon, 18²5'06"N, 6657'55"W, 210 m, 15 Jun 1996, Thompson $\&$ Rawlins 12689 (US); Guayama to Cayey, 27 Jun 1901, Underwood \& Griggs 449 (NY, US); Yauco, 14 Jun-22 Jul 1901, Underwood \& Griggs 613 (NY, US); Arecibo, Bosque Estatal de Rio Abajo, off Rt 10, along Rt 621, near picnic shelter, $18.32212^{\circ} \mathrm{N}, 66.68063^{\circ} \mathrm{W}, 306 \mathrm{~m}, 19 \mathrm{May} 2011$, Vincent et al. 15508 (NY); Mun. Quebradillas, Barrio Terra Nova, along rd on old railroad track to the Atlantic coast (between Rt. 4485 \& Rt. 2), $18^{\circ} 29^{\prime} \mathrm{N}, 66^{\circ} 56^{\prime} 30^{\prime \prime} \mathrm{W}, 40$ m, 28 Oct 1994, Zanoni et al. 47234 (FLAS, NY). U.S. VIRGIN ISLANDS. St. Croix: Blue Mountain, 23 Sep 1873, Eggers s.n. (S); East Ridge, Davis Bay, 16-8 Apr 1984, Liogier 35043 (NY); Crequis ledge, 11 Jun 1896, Ricksecker 429 (F, GH, MO); without definite locality, West s.n. (MO). St. John: along Center Line Rd by km 4.5, 3 Sep 1990, Acevedo-Rdgz. 2946 (MO); Cruz Bay Quarter, rd to Susannaberg, 212 m, 6 Jan 1991, Acevedo-Rdgz. \& Siaca 3809 (MO); Bethania, 5-7 Feb 1913, Britton \& Shafer 195 (F, US). St. Thomas: Grown Mountain, 1556 m, 12 Feb 1991, Acevedo-Rdgz. et al. 4210 (MO); hills N of Charlotte Amalie, 5-7 Feb 1913, Britton \& Marble 390 (F); S of Hull Bay, 23 Aug 1966, Stimson 4192 (DUKE, F). BRITISH VIRGIN ISLANDS. Virgin Gorda: north middle, slopes, 21 Jun 1969 , Woodbury s.n. (NY).

Miconia elaeagnoides is more broadly distributed geographically than most species of the Caribbean clade of Miconia, occurring widely on Hispaniola and Puerto Rico (Fig. 1), and also growing in the U.S. and British Virgin Islands. Therefore, it is not surprising that it is quite variable in leaf size and shape and in the size of the various floral parts (see description). Populations of Puerto Rico, the Virgin Islands, and Hispaniola cannot be reliably distinguished, but plants with more elongated calyx teeth (i.e., ca. $1 \mathrm{~mm}$ long or longer) are restricted to Hispaniola. However, many Hispaniolan plants have short calyx teeth, and are not distinguishable from populations of Puerto Rico or the Virgin Islands.

Iconography.-Beautiful illustrations of Miconia elaeagnoides are available in Britton (1928), Fournet (1978), Humboldt \& Bonpland (1816-1823), Little \& Wadsworth (1964), and Vahl (1796-1807). An illustration of the species is also included in Acevedo-Rodríguez (1996), but is less useful than the others because it 
shows 5-merous flowers, which actually represent an extremely rare condition within the species. An unpublished, watercolor illustration done in connection with A. Stahl's "Estudios sobre la flora de Porto-Rico," is also available on-line (at www.plantillustrations.org, as Tetrazygia elaeagnoides).

\section{ACKNOWLEDGMENTS}

We thank Kent Perkins, Collections Manager (FLAS), for assistance in processing and use of specimens. We thank the curators and staff of the herbaria (A, DUKE, F, GH, JBSD, MICH, MO, MSC, NY, S, US), who generously provided specimens on loan. We are also grateful for the helpful comments received from Kurt M. Neubig and an anonymous reviewer. This research was supported, in part, by National Science Foundation Grant BSR-0818399, and we thank Fabian A. Michelangeli for his administrative and professional assistance in connection with this grant-supported project.

\section{REFERENCES}

Acevedo-RodRiguez, P. 1996. Flora of St. John. Mem. N.Y. Bot. Gard. 78:1-581.

BÉCQUeR, E.R. 2012. Taxonomía de Pachyanthus (Melastomataceae: Miconieae). Brittonia 64:179-207.

Bécquer, E.R. \& F.A. Michelangel. 2011. Miconia walterjuddii (Miconieae: Melastomataceae), a new species from Cuba. Brittonia 63:425-429.

Bécquer, E.R., K.M. Neubig, W.S. Judd, F.A. Michelangel, J.R. Aвbott, \& D.S. Penneys. 2008. Preliminary molecular phylogenetic studies in Pachyanthus (Miconieae, Melastomataceae). Bot. Rev. 74:37-52.

Bécquer, E.R., W.S. Judd, \& L.C. Majure. 2017/18. Taxonomic revision of Miconia sect. Calycopteris (Melastomataceae, Miconieae) in Cuba. Brittonia 70:90-110. doi:10.1007/s12228-017-9493-1.

BRIQUET, J. 1906. Regles Internationales de la Nomenclature Botanique. Verlag von Gustav Fischer, Jena, Germany.

BRITTON, N.L. 1928. Tetrazygia elaeagnoides. Addisonia 13:53, pl. 443.

Britton, N.L. \& P. WiLson. 1925. Melastomataceae. In: Scientific Survey of Porto Rico and the Virgin Islands. New York Academy of Sciences, New York, U.S.A. Pp. 1-18.

Cogniaux, A. 1891. Melastomataceae. In: A. de Candolle \& C. de Candolle, eds. Monographiae phanerogamarum 7. Masson, Paris, France. Pp. 1-1256.

FouRnEt, J. 1978. Flore illustrée des phanérogames de Guadeloupe et de Martinique. Institut National de la recherché Agronomique, Paris, France.

Gamba D. \& F. AlmedA. 2014. Systematics of the Octopleura clade of Miconia (Melastomataceae: Miconieae) in Tropical America. Phytotaxa 179:1-174.

Goldenberg, R., D.S. Penneys, F. Almeda, W.S. Judd, \& F.A. Michelangeli. 2008. Phylogeny of Miconia (Melastomataceae): Patterns of stamen diversification in a megadiverse Neotropical genus. Int. J. PI. Sci. 169:963-979.

Humboldt, A. \& A. BonPLAND. 1816-1823. Monographia Melastomacearum, 2 vols. Lutetiae Parisiorum. [Melastoma elaeagnoides, pp. 28-30, t. 13.]

Howard, R.A. \& E.A. KeLlogG. 1986. Nomenclatural notes on Miconia (Melastomataceae). J. Arnold Arb. 67:233-255.

IONTA, G.M., W.S. JUDD, J.D. SKEAN, \& C.K. McMulLEN. 2012. Two new species of Miconia sect. Sagraea (Melastomataceae) from the Macaya Biosphere Reserve, Haiti. J. Bot. Res. Inst. Texas 6:37-44.

JudD, W.S. 2007. Revision of Miconia sect. Chaenopleura (Miconieae, Melastomataceae) in the Greater Antilles. Syst. Bot. Monogr. 81:1-235.

JUDD, W.S. 2019. Miconia rufinervis (Melastomataceae: Miconieae), an enigmatic endemic of the Massif de la Hotte, Haiti. J. Bot. Res. Inst. Texas 13:229-234.

JUDD, W.S. \& G.M. IONTA. 2013. Taxonomic studies in the Miconieae (Melastomataceae). X. Revision of the species of the Miconia crotonifolia complex. Brittonia 65:66-95.

JUDD, W.S. \& G.M. IonTA. 2017. Miconia vincentiana (Melastomataceae: Miconieae), a curious endemic to St. Vincent. J. Bot. Res. Inst. Texas 11:335-342.

Judd, W.S., E.R. BÉcQuer, \& L.C. MAJure. 2014a. Taxonomic studies in the Miconieae (Melastomataceae). XI. A revision of Miconia sect. Calycopteris on Hispaniola. Brittonia 66:216-249.

Judd, W.S., E.R. BÉcQuer, J.D. SKeAn, JR., \& L.C. MAJuRE. 2014b. Taxonomic studies in the Miconieae (Melastomataceae). XII. Revision of Miconia sect. Miconiastrum, with emphasis on the Miconia bicolor complex. J. Bot. Res. Inst. Texas 8:457-491. 
Judd, W.S., T. Clase, \& L.C. Majure. 2015a. First collection of Miconia alainii (Melastomataceae: Miconieae) with flowers. J. Bot. Res. Inst. Texas 9:449-451.

Judd, W.S., L.C. Majure, G.M. IontA, \& K.M. Neubig. 2015a. Taxonomic studies in the Miconieae (Melastomataceae). XIII. Systematics of Miconia subcompressa, a Hispaniolan endemic comprised of three eco-geographic subspecies. Phytotaxa 197:61-83.

Judd, W.S., L.C. Majure, J.D. SkeAn, JR., K.M. Neubig. 2015b. Miconia abscondita (Melastomataceae, Miconieae), a new species from the Massif de la Hotte, Haiti: Rediscovered in herbaria after being hidden for nearly nine decades. Rhodora 117:317-341.

Judd, W.S., E.R. BÉCQueR, \& L.C. MAJURE. 2017. First collection of Miconia turquinensis (Melastomataceae: Miconieae) with flowers, and comparison with M. remotiflora, a putative close relative. J. Bot. Res. Inst. Texas 11:161-167.

Judd, W.S., G.M. IontA, \& L.C. MAJuRE. 2018. Taxonomic studies in the Miconieae (Melastomataceae). XIV. Species of Miconia section Sagraea that occur in the Greater Antilles and additionally in the Lesser Antilles and/or continental regions. J. Bot. Res. Inst. Texas 12:531-547.

LitTle, E.L., JR. \& F.H. Wadsworth. 1964. Common trees of Puerto Rico and the Virgin Islands. Agricultural Handbook No. 249. U.S. Department of Agriculture, Forest Service, Washington, D.C., U.S.A. [Tetrazygia elaeagnoides, p. 424, t. 199.]

Lıogier, A.H. 2000. Melastomataceae. La Flora de la Española, vol. IX. Jardín Botánico Nacional “Dr. Rafael Ma. Moscoso," Instituto Tecnológico de Santo Domingo (INTEC), Santo Domingo, República Dominicana.

MAJURE, L.C. \& W.S. JudD. 2013. Miconia phrynosomaderma (Melastomataceae: Miconieae), a new species from the Massif du Nord, Haiti, and sixteen new names and combinations. J. Bot. Res. Inst. Texas 7:265-274.

Majure, L.C., W.S. Judd, G.M. Ionta, J.D. Skean, JR., E.R. Bécquer, R. Kriebel, M. Reginato, J. Burke, D.S. Penneys, G. Ocampo, M. Alvear, R. Goldenberg, F. Almeda, \& F.A. Michelangelı. 2013. Evaluating morphological evolution in tribe Miconieae (Melastomataceae): Homology is the rule not the exception. Botany 2013 Abstract ID:300.

Majure, L.C., W.S. Judd, G.M. IOnTA, J.D. SkeAn, JR., K.M. NeubiG, \& E.R. Bécquer. 2014. Miconia cineana, a new species from the Massif de la Hotte, Haiti, based on morphological and molecular evidence. Syst. Bot. 39:906-914.

Majure, L.C., W.S. Judd, \& F.A. Michelangeli. 2014/15. Taxonomic revision of the Greater Antillean Pseudolima clade of Miconia (Miconia sect. Krugiophytum: Miconieae: Melastomataceae). Brittonia 67:11-18. doi:10.1007/ s12228-014-9349-X.

Majure, L.C., K.M. Neubig, J.D. Skean, JR., E.R. Bécquer, \& W.S. Judd. 2015. Evolution of the sandpaper clade (Miconieae, Melastomataceae). Int. J. PI. Sci. 176:607-626.

Majure, L.C., E.R. BéCquer, \& W.S. Judd. 2016. Revision of the Lima clade (Miconia sect. Lima, Miconieae, Melastomataceae) of the Greater Antilles. PhytoKeys 72:1-99.

Majure, L.C., J.D. Skean, JR., K.M. Neubig, \& W.S. Judd. 2018. Miconia clasei, a new species of Miconia sect. Calycodomatia (Miconieae: Melastomataceae) from the Sierra de Bahoruco, Dominican Republic and a closer look at species relationships in the sandpaper clade. Syst. Bot. 43:430-438.

Martin, C.V., D.P. Little, R. Goldenberg, \& F.A. Michelangeli. 2008. A phylogenetic evaluation of Leandra (Miconieae, Melastomataceae) based on ITS data and its implications on inflorescence position. Taxon 53:279-290.

Michelangeli, F.A., W.S. Judd, D.S. Penneys, J.D. Skean, JR., E.R. Bécquer, R. Goldenberg, \& C.V. Martin. 2008. Multiple events of dispersal and radiation of the tribe Miconieae (Melastomataceae) in the Caribbean. Bot. Rev. 74:53-77.

Michelangeli, F.A., F. Almeda, R. Goldenberg, W.S. Judd, E.R. Bécquer, \& T.M. Tulig. 2009 onward. A complete web-based monograph of the tribe Miconieae (Melastomataceae). (http://sweetgum.nybg.org/melastomataceae). The New York Botanical Garden, Bronx, New York, U.S.A.

Michelangeli, F.A., F. Almeda, M. Alvear, E.R. Bécquer, J. Burke, M.K. Caddah, R. Goldenberg, G.M. lonta, W.S. Judd, L.C. Majure, J. Meirelles, A.N. Nicolas, G. Ocampo, D.S. Penneys, J.D. Skean, JR., \& C. Ulloa Ulloa. 2016. Proposal to conserve Miconia nom. cons. against the additional names Maieta and Tococa (Melastomataceae: Miconieae). Taxon 65:892-893.

Michelangel, F.A., R. Goldenberg, F. Almeda, W.S. Judd, E.R. Bécquer, G. Ocampo, G.M. Ionta, J. D. Skean, JR., L.C. Majure, \& D.S. PenneYs. 2018. Nomenclatural novelties in Miconia (Melastomataceae: Miconieae). Brittonia 71:82-121. doi 10:1007/ s12228-018-9546-0.

Michelangeli, F.A., A.N. Nicolas, G. Ocampo, R. Goldenberg, F. Almeda, W.S. Judd, E.R. Bécquer, J.D. Skean, Jr., R. Kriebel, K. Sosa, M.K. Caddah, G.M. Ionta, D.S. Penneys, M. Alvear, J.M. Burke, L.C. Majure, \& M. Reginato. Submitted. Historical biogeography of the Neotropical tribe Miconieae (Melastomataceae) reveals a pattern of progressive colonization from Amazonia to other Neotropical forests. J. Biogeog.

PENNEYS, D.S. \& W.S. JudD. 2005. A systematic revision and cladistic analysis of Charianthus (Melastomataceae) using morphological and molecular characters. Syst. Bot. 30:559-584. 
SKEAN, J.D., JR. 1993. Monograph of Mecranium (Melastomataceae-Miconieae). Syst. Bot. Monogr. 39:1-116.

SkEAN, J.D., JR. 2000. Mecranium juddii (Melastomataceae: Miconieae), a new species from the Massif de la Hotte, Haiti. Brittonia 52:191-195.

SKEAN, J.D., JR. 2010. Calycogonium bairdianum (Melastomataceae: Miconieae), a new species from the Cordillera Central, Dominican Republic. Brittonia 62:210-214.

SkEAN, J.D., JR., W.S. JudD, L.C. MAJURE, \& G.M. IONTA. 2018. Recognition of Miconia sect. Sagraeoides (Melastomataceae: Miconieae) and associated nomenclatural changes. Brittonia 70:342-355.

Tiernan, N.A. \& F.A. Michelangel. 2018. A revision of the Miconia ulmarioides complex (Melastomataceae: Miconieae). Brittonia 70:455-477.

Turland, N.J., J.H. Wiersema, A.M. Monro, Y.-F. Deng \& L. Zhang. 2017. XIX International Botanical Congress: Report of Congress action on nomenclatural proposals. Taxon 66:1234-1245.

VAHL, M. 1796-1807. Ecologae americanae, seu, Descriptiones plantarum praesertim Americae meridionalis, nondum cognitarum. Vols. 1-3. Havniae, impensis auctoris. [Melastoma elaeagnoides, vol. 3:27, t. 28.]

WURDACK, J.J. 1986. Atlas of hairs for Neotropical Melastomataceae. Smithsonian Contr. Bot. No. 63. Smithsonian Institution Press, Washington, D.C., U.S.A.

URBAN, I. 1921. Melastomataceae. In: Flora Domingensis. Symb. Antill. 8:490-505. 